\title{
Why Might Information Exacerbate the Gender Gap in Civic Participation? Evidence from Mali
}

\author{
Jessica Gottlieb \\ Assistant Professor \\ Bush School of Government \& Public Service \\ Texas A\&M University \\ 1037 Allen Building \\ 4220 TAMU \\ College Station, Texas 77843 \\ Email: jgottlieb@tamu.edu \\ Phone: +001 (979) 458-8018 | Fax: +001 (979) 845-4155
}




\begin{abstract}
Civic engagement fails to foster democratic representation when women or other marginalized groups face barriers to participation, as they do in many societies. Rather than flattening civic participation, a randomly assigned civic education course in Mali widened the gender gap when it increased civic activity among men while decreasing that among women. Qualitative data collected through focus groups and interviews reveal mechanisms by which the intervention generated these perverse consequences for women. In a place where women are traditionally unwelcome actors in the public sphere, female participation in the course constituted deviation from a pre-existing so-cial norm. As compensation, women self-impose limits to future civic participation and men erect new barriers as a form of backlash. These findings are consistent with the "re-source paradox" described in the literature in which increasing resources among women can yield negative outcomes when asymmetric or gendered social norms neutralize, or even invert, whatever benefits the resource confers on the woman. The civic interven-tion did, however, work to improve civic and political knowledge for men and women. Together, these findings suggest that resource constraints limit civic participation, but increasing informational resources cannot overcome discriminatory gender norms - and may even exacerbate them. One implication of the study is that future participatory interventions like this one should be more attuned to the social constraints faced by women and other marginalized groups to both avoid setting untenable expectation and anticipate reactions to breaches of the status quo.
\end{abstract}




\section{Acknowledgements}

I am grateful to the National Science Foundation, the International Growth Centre, the Freeman Spogli Institute, and Stanford University for financial support. I thank Jeremy Weinstein, James Fearon, Saumitra Jha, Katherine Casey, Beatriz Magaloni, Bernd Beber, Mariela Szwarcberg, Kristin Michelitch, Amanda Robinson, Eric Kramon, Guy Grossman, Rachel Glennerster and members of the Midwest Working Group on African Political Economy for comments on earlier drafts. This research would not have been possible without the research assistance of Sidi Zeda and Peter LeFrancois as well as the Malian instructors and enumerators. All errors are my own. 


\section{Introduction}

Despite increasingly egalitarian attitudes toward gender roles, there remains a substantial gender gap in civic participation worldwide, largest among agrarian societies Inglehart and Norris (2003); Verba, Schlozman, Brady, and Nie (1993). Well-known determinants of civic participation at the individual level - education and socio-economic status - fail to account for why women participate less than men Verba, Burns, and Schlozman (1997). And there is little evidence explaining the gender gap in civic participation, particularly in developing societies where the problem is most severe. This study generates micro-level data, both quantitative and qualitative, from one developing society that documents a perverse effect of a civic information intervention on the existing gender gap in civic participation and generates explanations for why. Unpacking the mechanisms underlying this unintended effect informs our understanding of the prevelant gender gap in civic participation, and what can and cannot be done to close it.

A large-scale field experiment in Mali forms the basis of the study. Originally designed to examine the impact of providing civics information on voter behavior Gottlieb (2015), the civics intervention did not have an overt gender component, though men and women participated in the course at nearly equal rates. This allows us to examine the following puzzle: will positive impacts from such an intervention accrue equally to both women and men, or will pre-existing gender norms result in a differential effect? There is support in the literature for both outcomes. A long literature substantiates the relationship between civic information and civic participation, and finds impacts on both genders Galston (2001); Verba et al. (1997). Specifically in the African context, Grossman, Humphreys, and Sacramone-Lutz (2013) find that reducing resource costs through information technology can flatten gender disparities in participation. On the other hand, a review of USAID programs finds that encouraging gender equality through civic education interventions unintentionally reinforces gender disparities in the political realm USAID (2002). In similar types of participatory

programs in India and Uganda, Cornwall (2003) discusses how programs intended to be 
inclusive instead exacerbate gender norms or reinforce male bias..$^{1}$

I find that asymmetric gender norms are sufficiently strong in the Malian context that they prevent women from enjoying the benefits of having participated in the civics intervention. What's worse, course participation appears to have a perverse (rather than a null) effect on women. While the course substantially increased civic participation among men, it decreased that among women. The quantitative data generated by logging civic activity of men and women in treatment and control groups in the months following the experimentally assigned intervention allows us to rigorously identify this phenomenon. I then draw on qualitative data to explain the mechanisms producing these results. Interviews and focus groups with male and female participants demonstrate that rural Mali is a place where women are traditionally unwelcome actors in the public sphere. Female participation in the course constituted a deviation from this norm, thus increasing social costs to future civic engagement among women. Examining inter-village differences, I find some evidence that the effect is worse where gender norms are strongest: in less urbanized and more traditional communities.

The perverse consequence documented in this study is consistent with what Mabsout and Van Staveren (2010) call the "resource paradox," or a phenomenon in which increasing women's access to individual resources decreases rather than increases their bargaining outcomes. Such an outcome arises when gendered institutions or asymmetric social norms Van Staveren and Odebode (2007) overwhelm whatever benefits the resource confers on the woman. Resources, such as information or money, are expected to improve outcomes for women not only by increasing their social or economic status or opportunities, but also by increasing their bargaining power Agarwal (1994); Quisumbing et al. (2003). However, asymmetric gender norms may neutralize this advantage "by affecting their exit options, their bargaining agency, for example, accepting male authority when they have formally equal rights, their preferences, through adapting these to what is deemed proper for women,

\footnotetext{
${ }^{1}$ And Jung, Ferree, Gibson, and Dowd $(2012)$ find that a get-out-the-vote campaign increasing awareness of the visibility of voting in Uganda in fact depressed female turnout.
} 
and their roles in the household, limiting what can and what cannot be bargained over" Mabsout and Van Staveren (2010). A negative, rather than neutral, effect can obtain when women compensate for the deviation from social norms (wrought by the relative improvement in resources) by being more strictly bound by those same norms. The randomly assigned civics intervention produces support for the resource paradox with its finding that increasing access to civic information and skills not only failed to close the gender gap but widened it. The qualitative data collected following the intervention suggests that, indeed, female participants deviated from an asymmetric norm against women's participation in the public sphere, and as compensation, constraints to future participation were both self-imposed by women, and erected by men.

The implications of these findings are nuanced. Information deficits did pose a constraint to civic participation among men which were rectified, at least in part, by a civic education intervention. And, it is not the case that women failed to gain anything from the civics course either. Women's civic and political knowledge improved significantly with treatment. The fact that these changes in knowledge and attitudes did not translate into changes in civic behavior for women as it did for men suggests that pre-existing gender norms rather than disparities in knowledge and skills are the binding constraint on female participation. While women may reap some benefit from improved civic skills and knowledge, closing the gender gap in civic participation requires the harder and longer work of changing gender norms.

This work adds to a growing evidence base on gender (in)equality in local development. Formally mandating female participation has been shown to improve gender equality in politics. In Afghanistan, requiring involvement of women in local elections and on village councils more than superficially increases female participation in local governance and has a demonstration effect of making women's political participation more acceptable Beath, Christia, and Enikolopov (2013). Similarly, electoral quotas in India continue to elicit greater female political and economic participation after they are withdrawn Bhavnani (2009); Chattopad- 
hyay and Duflo (2004). And a cross-country study on the African continent finds support for the idea that increasing representation of women in elected positions decreases gender disparity in political participation Barnes and Burchard 2013). However, gender norms are not quickly or easily transformed and can undermine egalitarian institutions as I find in Mali. In India, men still evaluate female politicians unfavorably due to strong distaste for female leadership (as opposed to poor performance) Beaman, Chattopadhyay, Duflo, Pande, and Topalova (2009); in China, women frequently have their ballots cast or filled out by others without their consultation Rozelle and Pang (2006); and even globally, when women are granted access to powerful political positions such as cabinet posts, these are far more likely to be in less prestigious sociocultural ministries than in those dealing with the economy or foreign policy Reynolds (1999).

This article additionally makes theoretical and methodological contributions to the literature on information and civic participation. While several existing studies have identified a conditional effect of information on civic participation by gender Finkel, Sabatini, and Bevis (2000); USAID (2002), I contribute theoretical intuition and explore mechanisms underlying the gendered impact of civic education. Previous studies attempt to address endogeneity problems of identifying the effect of information on civic behavior by controlling for confounding participant attributes Bratton, Alderfer, Bowser, and Temba (1999); Finkel (2002), but are still subject to bias from unobservable factors which an experimental design overcomes. Further, I demonstrate the utility of a novel measurement instrument - an event register - that I show produces more valid measures of civic participation than standard survey questions.

Finally, the findings of this paper raise an important ethical dilemma. While there are normative reasons Hill and Matsubayashi (2005) to want to encourage what Putnam would call "bridging social capital" in the interest of increasing democratic representation, there may also be important costs. The potentially perverse consequences of community-level programs that involve mixed gender participation highlight the need for more discussion across 
disciplines about how to avoid exacerbating female exclusion in male-dominated societies. The answer is not simple; as Cornwall suggests, there is often a tension between promoting women and supporting the poorest of the poor.

\section{Gender, civic participation and the Malian context}

I define civic participation as citizen engagement in public affairs with the aim of improving public life or influencing government policy. Political participation - the act of directly engaging in politics through party activity, electoral campaigns, or serving in public office is a subset of civic participation. While studies in American politics often focus on political participation Verba, Schlozman, and Brady (1995); Zukin, Keeter, Andolina, Jenkins, and DelliCarpini (2006), a broader definition of civic participation is more appropriate in a developing country context. Where political parties are weak and disorganized, electoral campaigns focused on patronage rather than policy issues, and formal channels of contacting public officials rare or ineffectual, political participation narrowly defined is a less useful avenue through which citizens can affect policy outcomes. Instead, organizing with other community members outside of formal political organizations can be a more effective way to pressure politicians or voice public opinion. In addition to the greater relevance of civic than political participation in a developing society, new evidence shows a greater gender gap in the former than the latter Isaksson, Kotsadam, and Nerman (2014).

There is a consistently large gender gap in civic participation across the African continent. Figure 1 plots the difference in an index of civic participation between men and women using the last three rounds of Afrobarometer data. ${ }^{2}$ While the direction of the gap always favors men, there is considerable variation in the gap both within and across countries.

Figure 1 about here.

To the extent that civic participation is a mechanism for individuals and groups to make

\footnotetext{
${ }^{2}$ The index is created by combining the following set of variables using a standardized weighted summary index: membership in voluntary association or community group, attendance at community meetings in the past year, joining others to raise an issue, and contacting one's local government councillor.
} 
their voices heard and hold leaders accountable, this empirical gender gap undermines the representativeness of government to its people. Gender-based inequities invoke Fiorina's Fiorina (1999) warning of the "dark side" of civic engagement whereby the interests of those most civically engaged are incongruous with the interests of the larger community. Dahl (1972) argues that a responsive government is contingent upon citizens having unimpaired opportunities to express preferences through individual and collective action. Achieving a better understanding of when and why we see a diverging gender gap in civic participation is thus a first step to improving the responsiveness of government.

The literature examining determinants of the gender gap in civic participation informs our understanding of how a resource shock - the provision of civic information and skills might lead to a local divergence in the gender gap in civic participation. Existing studies of developing nations largely disconfirm that resource differentials alone are responsible for the gender gap in civic participation 3 Across Latin America, individual-level characteristics such as education, socio-economic status and religiosity, cannot explain the gender gap Desposato and Norrander (2009). In Africa, Logan and Bratton (2006) find that differential levels of education and associational involvement only partly explain the gender gap in political participation. Similarly, Isaksson et al. (2014) find that resources such as information access, education and poverty explain only a modest share 4 These trends suggest that providing information or other resources to women alone, may not be sufficient to close the gender gap in civic participation.

The gender gap in civic participation across developing societies has more often been attributed to social and political institutional features. Isaksson et al. (2014) find suggestive

\footnotetext{
${ }^{3}$ The resource argument, however, has proven more viable in developed societies: Burns, Schlozman, and Verba (2001) find that gendered differences in the stockpile of education and employment in the US contribute to the gap in participation; across 70 mostly high- or middle-income countries Inglehart and Norris (2003) find that individual-level characteristics such as education, class and religiosity completely account for any gender gap in political activism; and Verba et al. (1997) find that gender differences in political information, interest and efficicacy are reproduced in measures of participation in the US.

${ }^{4}$ An exception is the study by Grossman et al. (2013) that finds reducing resource costs through information technology can flatten gender disparities in participation. One explanation for this inconsistent finding may be the nature of the outcome being studied: text-messaging politicians is a relatively anonymous, and thus less socially costly, form of civic participation.
} 
evidence that the gender gap across Africa is correlated with higher levels of perceived intimidation and clientelism and more unequal gender norms. Duflo (2012) argues that while there is a correlation between economic development and women's empowerment, the former is not sufficient to obtain gender equality because of persistent biases against female infants, against women in the workplace and against female leaders. Another consistent finding is that the gender gap in participation narrows when election results are allocated more proportionally across political parties Kittilson and Schwindt-Bayer (2012) that must reach out to a broader, more diverse base to win votes. Mali compares poorly with other African states on the participation of women in civic activity as shown in Figure 1. Below, I discuss some institutional features of the Malian context that help account for its poor standing.

\subsection{The Malian context}

Women are widely considered a marginalized social category in Malian society Bleck (2011). One reason for disenfranchisement arises from customary land law as women are traditionally unable to own land. They are also discriminated against in the legal code: marriage age for women is lower than for men; women need their husband's permission to open a business; as the head of the family, the husband controls household finances and choice of residence; and women are legally bound to obey their husbands. Widespread social norms such as domestic violence against women and high rates of female circumcision also negatively affect female engagement in the public sphere. Given the disadvantaged status of women under customary relative to formal law in Mali, the ongoing categorization of family law as private has "left women's rights unprotected and challenged by restricted notions of tradition" (Wing, 2012 , $152)$.

A closer look at Bambara gender ideology reveals some cultural explanations for these formal and informal gender norms. Bambara is the majority ethno-linguistic group in Mali (and in the experimental sample) and as such, may influence other groups. According to 
Turrittin (1988), "Men are structurally dominant because belief in male superiority legitimates their control over the jural-political domain as well as over women's reproductive and productive labor power; men are considered the most important agricultural workers." Women have some power independent of their husbands that derives from their child-bearing capacity and services as domestic workers, but economically, they are inferior.

While urbanization and economic development often bring with it improved gender relations, this is not necessarily the case for the Bambara. Patrilineal norms governing lineage gives men privileged access to land, labor and technology. Further, traditional cultural definitions governing appropriate marketing activity for men and women (who trades which goods, who buys and who sells) has given men an even greater advantage. According to Wooten (2003), "the male-centered patterns of access to key productive resources that characterize the food economy are echoed in the realm of production for cash: men, particularly senior married men, have priority access to the most lucrative domains." Specifically, men farm the most productive land and are responsible for providing staple products for meals, but otherwise keep income from surplus crops to invest or spend on themselves. Women cultivate smaller vegetable plots for both household consumption and market trade. With revenue from their surplus yield, women are responsible for children's education, clothing and other household expenditures.

Relative to other African countries, women in Mali also participate in formal politics at very low rates. In 2013, Mali ranked in the 20th percentile for the share of women in the national parliament with 10.2 percent of representatives being female. 5 This is consistent with the fact that Mali is now in the minority of African countries that does not have a legislated gender quota or reserved seats for women.

Given all this, it is not surprising that Mali ranks 131 of 134 on the Global Gender Gap Index, which measures and aggregates gender inequalities across the domains of health, education, economy and politics. Because of Mali's position as a relative outlier on gender

\footnotetext{
${ }^{5}$ Data on share of members of parliament who are female taken from The Global Gender Gap annual reports.
} 
inequality, the cautionary tale in this study is not necessarily applicable to other low-income countries. However, the stark differences between genders makes Mali a useful case for exploring the mechanisms underlying the resource paradox, or the constraints placed upon female empowerment by asymmetric gender norms. Exploiting the heterogeneity within Mali in the last section will also suggest contexts to which lessons from the study should best generalize.

\section{Measurement strategy}

Identifying the effect of information and skills on civic participation poses a measurement problem. Citizens who do not participate in civic life are likely to be less well-informed or skilled because acquiring relevant information or skills is inherent to civic participation itself. A randomly-assigned information intervention overcomes this endogeneity problem. Average differences in civic participation between the treatment and control group can be attributed to the effect of information on civic engagement rather than the other way around. And assessing outcomes in a representative sample of men and women in treated and control villages produces a valid measure of the effects conditional on gender.

Though the findings of the experiment are rigorously estimated, they are incomplete. Because of the sensitivity and normative nature of the subject matter, survey items on a questionnaire do not reveal why women participated less in civic activity, only that they did. To better understand the mechanisms underlying this causal relationship, follow-up interviews and focus groups described in Section 6 aim to expose the chain of events that led to diminished civic participation among women.

\subsection{Treatment: a civics course}

In early 2011, I implemented a field experiment in 95 rural communes in Mali in which a civics course was randomly assigned to some communes and not others. Communes are 
subdivided into an average of 18 villages with about 1000 people per village. The treatment is conducted at the village level rather than the commune to ensure a more representative sample of commune residents can access the treatment. Provided at one-week intervals, the course consists of two or three half-day sessions conducted by a trained Malian instructor in the local language. The location of the course was selected in collaboration with the village chief, but was generally a public space within the village. In treated communes, individuals voluntarily self-select into treatment following a village-wide assembly that provides details about the course and an invitation to participate. Gender balance among participants was nearly achieved as women account for 43 percent of participants (women comprise about 50.5 percent of the population in the sample regions).

As might be expected, participants differ systematically from non-participants within the treatment communes.$^{6}$ The average age of participants was 45, higher than the average age among survey respondents of about 40 years old. Participants are better socially connected than non-participants: about 48 percent of self-reported participants (which includes some people who said they participated but likely did not) are related to the chief compared to only 34 percent of other respondents. They are less likely to be from a minority ethnic group in their village, and are better educated. 70 percent of self-reported participants say they attended some school while only 56 percent of other respondents report any schooling.

To overcome the issue of voluntary participation and thus self-selection, I assess treatment effects on the village by surveying a random sample of villagers who were not necessarily participants in the course. While this approach cannot rigorously identify the effect of the course on participants (because I do not have a proper counterfactual of would-be participants in control villages), it can rigorously identify the effect of the course on the village. Advantages of estimating the intent to treat rather than a treatment effect on the treated are

\footnotetext{
${ }^{6}$ Some participants details were collected during the course itself; others are from survey data. I infer course participation from affirmative answers to two survey questions about awareness of a civics intervention in the village and participation in that civics intervention. Likely due to affirmation bias, there is dramatic over-reporting of participation as evidenced by a quarter of respondents from the control group saying they participated in a civics course. To my knowledge, there was no other civics course carried out in sample communes in recent years.
} 
that it captures expected spillovers effects among residents of the same village and, thus, is likely of more interest from a policy perspective in that it can estimate the total effects of the intervention. Given the expectation of spillovers, an individual-level randomization design would be more likely to violate the Stable Unit Treatment Value Assumption (SUTVA) as the control group would also be affected by the treatment.

The civics course provides information about the rights and responsibility of citizens in the democratic process.7 Importantly for this analysis, the course discusses ways that citizens can participate in the governance of their commune - by participating in public meetings, by staying informed about the government's activities, by lobbying the commune council for community needs, and by making informed decisions at the ballot box. Participants are also provided details about the activities that fall under the local government's jurisdiction, namely, the provision of local public goods. Because Mali is a secular state, the course highlights the fact that support for religious and traditional activities fall outside the government's domain.

While the course did not have a specific gender focus, it highlighted the idea of equal treatment under the law. For example, it taught that, in elections, the voice of every person holds equal weight - including that of women, youth, and handicapped individuals. Furthermore, the head of the village women's association was often enlisted by the course instructor to help encourage women to participate in the course.

\subsection{Survey}

Three months after the implementation of the civics course, a follow-up survey measures differences in outcomes between treatment and control groups. Because of the aforementioned issue of self-selection of participants into treatment at the village-level, I mitigate potential bias by studying the effect of treatment on the entire village. The survey is thus conducted on a stratified sample, in which one of the strata consists of six randomly-selected households

\footnotetext{
${ }^{7}$ Details and curriculum outline are available in Appendix $\mathrm{F}$ As it was not the original intent of the course, there is no explicit treatment of gender issues in the curriculum.
} 
(chosen by random-walk method) from each village rather than just participants from the course. The second strata consists of four targeted local leaders: the women's leader, the youth leader, the head of the village association, and the village assistant elected during the civics course. These leaders are targeted because they are more likely to have participated in the civics course and to permit evaluation of differential impacts of the course across these household types. The survey and accompanying event register are conducted with one person in the 10 different households in each of the sample villages. Of the six randomly selected households, survey participants are stratified on gender.

\subsection{Sample}

The experimental sample consists of the 95 rural communes in the five cercles or districts of Kati, Koulikoro, Segou, Macina, Baraoueli. These cercles, located along the Niger River, are in two of Mali's most populous regions, Koulikoro and Segou. Each commune is randomly assigned to one of three groups: control, a first treatment arm or a second treatment $\operatorname{arm} 8$ The second treatment arm provides an additional course session on local government performance that is not given to the first treatment group. Because the distinction between treatment arms is not relevant for this analysis, I pool the treated groups together. The intervention in the 64 treated communes took about two months to complete. The control group does not receive any intervention and is visited by members of the research team for the first time during the follow-up survey.

Using a block randomization design, I stratified the sample on three variables related to information provision and government accountability: geographic region, whether the mayor elected in 2009 is an incumbent, and a commune-level development index. Due to budget and time constraints, I treated 5 randomly selected villages plus the commune seat in each commune in the sample. The total number of villages in the experimental sample is 556 .

Treatment and control communes are not clustered geographically so spillover from treat-

\footnotetext{
${ }^{8}$ See Appendix /refsec:map for a map of treatment assignment across communes.
} 
ment into control communes is thus a possibility. This concern is mitigated by the fact that sample communes are spread over vast terrain with poor road infrastructure linking one village to another. Further, information that spills over into control communes would bias the estimated treatment effect downward, making spillover effects less of a concern for the purpose of this analysis.

\section{Data and estimation}

To understand whether and for whom treatment affected civic engagement, I combine demographic data from the survey with data on participation in civic activity from a civic event register. Standard self-reports of the frequency of civic participation are subject to social desirability bias. If treatment increases participant beliefs about the desirability of civic participation, then survey measures risk confounding changes in beliefs with changes in actual behavior. I designed a measurement instrument to reduce this type of survey bias - a civic event register.

For comparison, I first construct a more standard Survey activity index. Survey respondents are asked the frequency with which they participated in each of four activity types: attending village meetings, attending commune meetings, getting together with a group to address a problem, or petitioning a leader. Response options include often, sometimes, once or twice, and never $\square^{9}$ Assigning ordinal values to these response categories, the index averages over responses to these questions.

When the participant responds affirmatively to participating in any one of four types of civic activity, the enumerator then asks the respondent to describe participation in every discrete event that falls under each category. The enumerator records all responses in the register. Each observation includes the date, number of people involved, details about the issue at hand, and any follow-up or response. Subsequently, each event is anonymously verified by either the village chief or commune secretary. Fewer than one percent of reported

\footnotetext{
${ }^{9}$ The question wording on my survey is adapted from the Afrobarometer.
} 
activities were not verified. The number of civic events reported per person is significantly correlated at 0.56 with the Survey activity index 10

From a total of 6000 events, 2915 survey participants, or 52 percent of the sample, report participation in at least one event in the included categories. The primary dependent variable, Civic event indicator, is a binary measure of whether the respondent reported at least one civic event (see Appendix C for details on the construction of this variable). Such an indicator answers the question of whether treatment inspired new entrants into civic life as opposed to whether treatment generated a marginal increase in civic participation. Count data is subject to greater measurement error resulting from variation in enumerator effort to record multiple events as well as participant patience in recounting multiple events. The count data also contains several outliers that disproportionately affect the analyses. I report analyses using the count dependent variable and dropping extreme outliers in Appendix E.

Because the dependent variable is measured at the individual level but treatment assignment is at the commune level, I use a mixed model fit using restricted maximum likelihood to account for dependence among individual observations within villages and among village observations within communes.11 Average treatment effects on individual-level outcomes $y_{i v c}$ for individual $i$ in village $v$ in commune $c$ are estimated using the following equation:

$$
y_{i v c}=\beta_{0}+\beta_{1} T_{c}+S_{i v c}^{\prime} \Sigma+Z_{e}+W_{b}+\alpha_{c}+\gamma_{v c}+\varepsilon_{i v c}
$$

where $T_{c}$ is an indicator of whether the commune received treatment, $\beta_{1}$ is the parameter of interest measuring average treatment effects, $S_{i v c}$ is a vector of individual-level controls, $Z_{e}$ are fixed effects for enumerator, $W_{b}$ are fixed effects for block, the unit on which randomization was stratified, $\alpha_{c}$ are random effects for commune, $\gamma_{v c}$ are random effects for

\footnotetext{
${ }^{10} \mathrm{I}$ do not distinguish between the four types of reported activities (attending meetings, contacting leaders, etc.), but rather whether or not a respondent reported participating in any activity. There is little theoretical distinction between differential treatment effects on any particular activity type and the lines between activity types are blurred. For example, some respondents attended a village meeting at which contacting their leader was discussed. The order in which the questions are asked also generates bias - there are four times as many reports of attending village meetings compared to getting together with a group to address a problem even though many of the reported activities across these two categories are not substantively distinct.

${ }^{11}$ I use the xtmixed command in Stata.
} 
village nested within communes, and $\varepsilon_{i v c}$ is an error term. Standard errors are clustered at the commune level, the unit of randomization. 12 To assess heterogeneous treatment effects, I interact the binary treatment indicator with an indicator variable for gender. Studying heterogeneous effects on women were proposed in a pre-analysis plan.

To further increase power of the analysis, I include individual-level controls that have a direct relationship to the dependent variable. The binary variable Woman takes a value of 1 if the respondent is a woman. Members of minority ethnic groups are indicated by the variable Minority. A respondent is coded as a minority if she belongs to an ethnic group to which less then a quarter of the other survey respondents in that village belong. 12 percent of respondents are coded as minorities. As a measure of wealth, I include Asset ownership, a binary variable that takes a value of 1 if the respondent's household owns either a television, car or motorcycle (about two-thirds of the sample). Chief relation is a binary indicator that takes a value of 1 if the participant is biologically related to the village chief (39 percent of sample). The binary variable Leader takes a value of 1 if the person is one of the 4 targeted leaders surveyed, and 0 if the person is from one of the 6 randomly selected households. Schooling takes a value of 0 if the participant reported no schooling, 1 if informal or some primary schooling was reported, and 2 if the participant completed primary or higher levels of education. About 60 percent of the sample reports any schooling, and only 12 percent of those completed primary school or higher. Because age is measured as a categorical variable placing individuals in 10-year bins of increasing value, I employ fixed effects for age or a binary variable for youth. I report balance tests on these covariates in Appendix B.

\section{Analyzing effects of the information intervention}

Before analyzing the effect of the experimental intervention on civic participation, I first check to determine whether the information was successfully integrated by participants and

\footnotetext{
${ }^{12}$ Though the dependent variable is binary, I report results of a linear regression model for ease of interpretation. Results are robust to logistic regression.
} 
whether comprehension of the material is conditioned by gender. Three pre-existing gender disparities raise the possibility that women would acquire less knowledge from the intervention than their male counterparts. First, women are less likely to have experience with political information: they report never listening to the radio 8 percent more often than men and listening everyday 15 percent less often. To the extent that formal education is necessary to comprehend civic information, women are also at a disadvantage as they report receiving formal schooling 18 percent less than men. And to the extent that pre-existing skills or personal connections facilitate future participation, women again fall behind men. Women's engagement in local associations is primarily confined to women's associations rather than mixed-gender groups. While 75 percent of women surveyed reported participation in the local women's association, they participate a quarter as much as men in parent-teacher and professional organizations, a fifth as much in village associations and less than a tenth as much in youth associations.

\subsection{Effects on knowledge}

I examine treatment effects on civic and political knowledge of local government, and whether these effects differ across genders, using a Knowledge index. This mean effects measure equally weights 15 component questions from the survey testing knowledge of which public services fall under local government jurisdiction, the local budget, the name of the commune, the name and party of the mayor, the names of commune councilors, who selects the mayor, what town hall meetings should cover, and events in the commune. Column 1 of Table 1 shows treatment significantly improves knowledge, and that this effect is not conditional on gender. Columns 2 and 3 show that treatment significantly increases knowledge in both gender groups, and by about the same amount.

Table 1 about here. 


\subsection{Within-village transmission of information}

An average of 30 villagers participated in the course per village. With a little over 1000 residents in the average village, this is a small proportion of course participants. Therefore, it may seem surprising if any impacts of the intervention are detected by the survey instrument which samples households regardless of participation in the course. Tight-knit social networks within villages are an important conduit of information and may be contributing to within-village information spillovers. In an experimental information intervention in Pakistan, for example, treatment effects were just as large on untreated female neighbors as they were on treated women Gine and Mansuri (2011).

One characteristic of Malian villages that facilitates the spread of information is the concession, a compound or a grouping of households comprising members of the same extended family. Households of the same concession live in close proximity, often enclosed by a single wall. The women of a concession typically prepare food together and the men often farm the same or neighboring plots of land. Gine and Mansuri's information experiment found that information only traveled successfully within networks of the same gender, which is likely similar in Mali given the structure of social and economic activities. However, the present experiment targets both men and women and succeeded in reaching almost equivalent numbers of each gender.

On average, 193 adult members of treated villages share a concession with at least one course participant. Considering that about half of village residents are under the age of 18 , we can estimate that about two-fifths of adults in the average treated village either attended the civics course or share a concession with another adult who did. Thus through the spread of information within concessions, treatment could have indirectly reached a relatively high proportion of village residents, to say nothing of the potential for information to spread between concessions. During a follow-up survey, a small number of participants and nonparticipants were asked about information dissemination regarding the civics course. About half of participants said they spoke about the course to other members of the village, and 
about a third of non-participants said they learned something about the course from people in their community.

\subsection{Effects on civic participation}

Table 2 presents aggregate treatment effects, unconditional on gender. Here, I regress the dependent variable - the Survey activity index in Column 1 and the Civic event indicator in Column 2 - on a treatment indicator and control variables ${ }^{13}$ Results suggest no net effect of treatment in the case of civic event indicator and a positive effect of treatment $(p=0.11)$ in the case of the survey measure. Within-subject comparisons suggest that participants are more honest in self-reporting participation in the event register relative to the survey measure.

Because the civic event register requires the respondent to provide detailed information about each event, it is more difficult to fabricate responses. This is borne out in the data: 836 respondents, or 15 percent of the sample, reported engaging at least occasionally in civic activities on the survey but then failed to provide accounts of civic engagement in the event register. By contrast, only 61 people, or 1 percent of the sample, reported never engaging in civic activities on the survey and then described at least one civic event on the register.

One explanation for the discrepancy between measures is social desirability bias. If respondents in the treatment group learned that civic engagement is normatively desirable, they are more likely to dishonestly report engaging in civic activity. The positive effect on the survey index may thus be a result of a treatment effect on norms rather than actual behavior.

Indeed, treatment makes people more likely to report civic participation on the survey than on the register. I test this by creating a dishonesty index in which I subtract the total number of events reported on the register from the Survey activity index calculated from the survey. The greater this difference, the more likely they say they engaged in civic activity

\footnotetext{
${ }^{13}$ See Appendix $\mathrm{D}$ for an analysis of treatment effects on the full register of civic events and excluded categories.
} 
on the survey without backing it up with reported events on the register. Treatment is positively correlated with dishonesty. For this reason, I conduct the remaining analyses in this paper using only the civic activity register as the dependent variable.

Table 2 about here.

In all cases, the relationship between the control variables and civic participation go in the expected direction. Schooling, leadership, relationship to the chief, and economic assets are all positively and significantly correlated with civic engagement. Conversely, membership in a marginalized group such as women, youth, and minority ethnicities is negatively and significantly associated with civic engagement. Age (dummies suppresed in the table) has the expected quadratic relationship where middle aged individuals are more likely to participate and elderly individuals are less likely to participate. 14

Though we see no aggregate treatment effects, I examine whether treatment has effects conditional on gender in Table 3 as proposed in a pre-analysis plan. Column 1 uses the aforementioned multilevel model that includes village random effects nested within the commune. Column 2 adds control variables that were found to predict participation in civic events to increase precision of the estimate of treatment effects. The coefficients on the interaction term in each of these models are large, negative and significant implying that treatment was significantly less effective at improving civic participation among women than men.15. While treatment has a negative effect on women, the effect on men is positive and significant. These countervailing effects offset each other in the aggregate analysis, explaining the lack of a net effect in Table 2

Table 3 about here.

From a baseline of 63 percent among men, treatment increases participation in civic activity by 4.6 percentage points. In contrast, from a baseline of 38 percent, treatment

\footnotetext{
${ }^{14}$ The null treatment effect for the civic event register is robust to the exclusion of controls and to using commune-level clustered standard errors rather than the mixed effects model. The positive effect on the survey index shrinks in size and significance under this simpler model.

${ }^{15}$ Similar results obtain with the count variable (see Appendix E) and with the full civic event register (see Column 1 of Table A.II Appendix D). The negative, significant coefficient on the interaction term also obtains when the treatment is disaggregated into $\mathrm{T} 1$ and $\mathrm{T} 2$.
} 
decreases participation by 5.9 percentage points among women, all else equal. Further tests of the data suggest that it is changes in behavior by the most marginalized women, youth and non-leaders, that are driving results. The latter four columns of Table 3 re-run the analysis on subsets of the female participant data by leader status and age, defining youth as below 45 years of age.

\section{Why women participate less}

The gendered treatment effect on civic participation is not driven by differences in comprehension. Even if it were, this would not explain the negative effect on female participation. Previous discussion suggests that negative consequences resulting from providing additional resources to women may be explained by the existence of asymmetric gender norms. To investigate whether and how the role of gender norms might substantiate findings of the quantitative analysis, I exploit additional qualitative evidence. These data were collected two years after implementation of the civics course in 16 treated villages distributed proportionally among the five sample districts. Follow-up visits in each village consist of one female-only focus group (with the women's group leader, at least two female course participants, and at least one nonparticipant) and individual interviews with at least two male course participants and the village chief ${ }^{16}$ A total of 112 people were interviewed: 64 women, 33 men and 18 village chiefs (or their proxies).

Transcribed texts from the focus groups and interviews ( 110 pages) were repeatedly reviewed to discern patterns in responses about gender norms and discrimination from the male and female perspective. Subsequent reviews identified participant responses that reflected major themes in the texts. Where possible, I quantify these responses. Oftentimes, however, I use illustrative quotes that the interviewer suspects are representative of broadly-shared but unspoken beliefs about gender norms and experiences of gender discrimination. Given

\footnotetext{
${ }^{16} \mathrm{~A}$ female-only focus group was the preferred method chosen in collaboration with the local research partner who believed women would be more at ease in a focus group than one-on-one interview setting.
} 
its sensitive nature, these beliefs or experiences expressed openly by some respondents are likely under-reported or misrepresented by others. For instance, many women said they were at ease during the course, but later confided the opposite in private conversation with the interviewer. Similarly, men often claimed to support gender equality during the interview but later made remarks to the contrary in informal conversation.

Because I am interested in mechanisms that explain the decrease in female participation, I target villages where this phenomenon is most evident: where women report no civic participation and at least half of men report participation. As a counterfactual, follow-up visits are conducted in four outlier villages, ${ }^{17}$ or places where women participate as much or more than men. Outlier villages are used to identify scope conditions for generalizing lessons from the study in Section 6.3 below.

\subsection{Course exacerbates asymmetric gender norms, increasing bar- riers for women}

The resource paradox argument suggests that women may be worse off when granted resources if they compensate by submitting to an even greater extent to an asymmetric social norm. These data suggest this was the case in Mali. I first show there is first a deeply held asymmetric gender norm around participation in local, village-level decision-making. Especially because the civic education intervention encouraged open discussion of issues of importance to the village community, female treatment participants could be considered as deviating from this social norm. Women might respond by limiting their own future civic behavior as compensation; or women may be subject to explicit constraints erected by men as punishment for deviation. Qualitative evidence uncovers evidence of both mechanisms women fail to participate because of having previously surpassed their limits, and because of overt threats or sanctions from men 18

\footnotetext{
${ }^{17}$ Villages 5, 6, 14, and 15 .

${ }^{18}$ A slightly different, but consistent interpretation is that the intervention made civic activity more salient, and community members paid closer attention to acts of local civic participation, increasing the likelihood
} 
Underlying both scenarios is a commonly held belief among both men and women that politics and civic life fall under the purview of men. Chiefs in only 2 of the 16 villages say they ever ask a woman's opinion when making decisions about the village. One man said, "Women have nothing to do with civic or political activities, on the other hand, they should only busy themselves with taking care of their home - that's their place.119 This sentiment is explicitly echoed by 10 other male participants and five chiefs. ${ }^{20}$ Another man said, "In the home, man is chief, so it follows that outside the home, men and women are not equal; in other words, men should always be in front.:21 The chief's proxy in another village added, "Whatever the education level of the woman, she remains inferior to men."22 And the chief himself stated, "according to our tradition, in all decisions taken here, women do not have a word to say.'23 Women internalize this belief as expressed in the focus group: "We think it is not our role to engage in communal activities, we think it is for men to do.'24

In five cases in which men say that women play an important role in the community, they later admit they would never discuss civic matters with their wives. This contradiction can be explained, in part, by the fact that certain income-generating activities fall in the women's domain such as gardening and trading low-cost goods at market. While this custom substantiates the claim that women play an important role in the development of the community, it does not follow that women should be engaged in decision-making that affects the community. As one village chief explains, women should engage in activities proper to their gender, and in doing so, the village advances; however, when it comes to decision-making regarding the village, women have no place $\stackrel{25}{25}^{2}$

that women's participation would be noticed and sanctioned. A similar phenomenon occurred in the Democratic Republic of Congo when radio shows aimed at encouraging peaceful reconciliation instead made grievances more salient and led to perverse outcomes Paluck (2010).

${ }^{19}$ Interview M2, Village 1.

${ }^{20}$ Interviews M1-2, Village 2; M1-3, C1-2, Village 3; C1, Village 6; M1-2, Village 8; C1, Village 12; M1-2, Village 15; M1, C1, Village 16.

${ }^{21}$ Interview M1, Village 8.

${ }^{22}$ Interview C2, Village 3.

${ }^{23}$ Interview C1, Village 3.

${ }^{24}$ Focus group, Village 3.

${ }^{25}$ Interview C1, Village 6. 
Anecdotal reports from course instructors confirm the commonly held belief that women have no place in civic affairs. Many village chiefs resisted the inclusion of female participants in the course because of a preference for the traditional decision-maker to represent local families. While course instructors were generally able to overcome such resistance by enlisting the help of a female leader, this challenge to traditional authority and existing norms may have contributed to a backlash.

When asked directly why women participate less, men blame it on women who "lack ambition to develop the community" and "who think it's the men's job to conduct such activities" as well as a lack of authorization from the village chief. ${ }^{26}$ They also cite women's lack of time due to household chores, incapacity to comprehend, laziness, lack of authority and charisma, spirit too weak to defend their interests, and poor ideas. In fact, one woman even said her husband was surprised by her participation because he thought she "was unable to take a decision" on her own 27

Many women agree that a lack of authorization from their chief or household head prevent them from engaging more, but few say they are constrained by a lack of understanding, spirit or good ideas. While some cite household chores and the need to undertake revenuegenerating activities to feed their children as a priority over civic activities, ${ }^{28}$ women more often cite religion or tradition as impeding their participation 29 as they learn from a young age that their place is "behind their husbands." Many say the course made them want to participate more, but they are not adequately consulted or invited to participate in fora where decisions are taken. 30 Others blame the illiteracy of their husbands who refuse to let them participate 31 Some women who attended meetings say their husbands speak for or intimidate them, undercutting the ability to express themselves. ${ }^{32}$

\footnotetext{
${ }^{26}$ Interviews M1-2; Village 3.

${ }^{27}$ Focus group F2, Village 8.

${ }^{28}$ Focus group, Village 12 .

${ }^{29}$ Villages 2, 5, 6, 7, 14.

${ }^{30}$ Focus groups L, Village 1; L, F2-3, Village 8; Village 10.

${ }^{31}$ Focus group L, Village 13.

${ }^{32}$ Focus group, Village 2. Focus group P1, Village 10.
} 
Responses from both genders indicate that female participants in the course deviated from existing gender norms, thus decreasing likelihood of their future participation. Some women report implicit threats of sanctions for engagement following the course. One says, "We are scared of imposing ourselves in civic affairs for fear that our husbands will think we have surpassed our limits because we took a course on democracy.' 33 Another says she felt ill at ease during the course itself and, in particular, was afraid to speak in front of men. A village chief in one region substantiates these fears: "Women's participation in these activities should have its limits...an educated woman will forget that she is inferior to men and could even fail to obey her husband. Our custom requires total submission of women to men. A chief from the other region echoes that men were angry about female participation in the civics course because they were threatened by the idea of women being their intellectual equals. One male participant expressed unhappiness that women participated in the course saying, "men are different in terms of competence, intelligence, courage and perseverance. $\sqrt{35}$

Barriers to future participation could also have increased if the course angered men or traditional authorities who disapprove of the equal and joint participation of both genders in the civics course. More explicit attempts by men - both husbands and village elders to repress women's participation were reported. One woman said, "After the civics course, some women and I decided to approach the mayor to install a mill in our village, but the men wanted it to be them who handled it instead of us doing it ourselves: $\sqrt[36]{36}$ In the same village, women reported getting together to acquire a bank loan for development activities until the effort was shut down by their husbands ${ }^{37}$ In another village, the chief would not authorize women to lobby the mayor following the course because he said it was the men's job to defend the interests of the village ${ }^{38}$ And in one case, men were not opposed to women's participation in the course at the outset, but felt threatened once they saw women trying to

\footnotetext{
${ }^{33}$ Focus group F2, Village 1.

${ }^{34}$ Interview C1, Village 6.

${ }^{35}$ Interview M2, Village 8.

${ }^{36} \mathrm{~L}$, Village 3.

${ }^{37}$ Focus group F1, Village 3.

${ }^{38}$ Village 16.
} 
take action. Opposed to this breach in tradition, men reported disliking the implication of women in activities that are none of their business 39

The course may have even improved the capacity of elites to enforce traditional norms. Indeed, it had a significantly greater impact on the male leaders surveyed than the male non-leaders. Because these leaders are significantly more likely to be related to the chief, they may also be more likely to defend traditional norms in the village. The fact that young women seem to be affected more than older generations further strengthens the sanctioning argument since the young are another lower status group in Mali.

\subsection{Alternative explanations}

One competing explanation for the decline in female participation is men and women are optimizing activities at the household level. Rather than experiencing a perverse effect of treatment, women may be doing what is instrumentally best for their family. Believing that men are more adept at participating in the public sphere, a household might decide to reallocate its time budget such that men spend more time engaging in civic life and women spend less. Because such a mechanism requires discussion of civic life by men and women in the same household, one observable implication of this phenomenon would be a convergence of local priorities across genders.

The survey asks respondents to rank several common needs in the village - water, health, education, roads, agricultural products, telecommunication and village gardens - by priority level. Women are significantly more likely than men to prioritize water and significantly less likely to prioritize education and roads. If priorities by gender converged somewhat following treatment, this would be evidence in favor of the idea that men and women discussed civic life in the home. There is, however, no evidence for this in the survey data. Regressing indicators for treatment, gender and their interaction on the priority level for each local need reveals no significant impact on convergence in priorities across gender. The qualitative evidence

\footnotetext{
${ }^{39}$ Village 2.
} 
does not support the household optimization mechanism either as women in 15 of the 16 villages report either discussing the course with other women in the village or not discussing the course with anyone. The only exception is an outlier village where one woman reports discussing the course with her husband and another with her brother - but in this village, women participate more, not less than men. 40

Another competing explanation for the differential treatment effect on civic participation is that women exit the formal system and instead engage more in the informal system. As one test, I examine how women's attitudes and behavior changes with respect to their customary village chief as compared to the elected mayor. If it were the case that women were exiting the formal system in favor of the traditional system, treatment should increase the extent to which women trust in or contact the chief relative to the mayor. Using survey responses, I find no evidence that treatment causes women to trust or contact the chief strictly more, or more relative to the mayor. Women are also no more likely to report membership in associations as a result of treatment. Further, discussion in female focus groups did not generate evidence of disillusionment in the formal system. To the contrary, there are several examples of women attempting to engage in civic activity following the course but being thwarted by husbands or male leaders.

Finally, the course may have had a crowding out effect. If participation is a zero-sum game, then more participation by men implies less participation by women. While there is no direct evidence of this, I cannot rule it out with available data. If true, one solution to mitigate the perverse impact on women would be to provide the course to women only. Since this may further anger male elites, such an intervention would require further research.

\subsection{Generalizability}

A closer look at the four outlier villages that exhibit either no gap in civic participation or a female-dominated gap generates possible scope conditions for generalizing the perverse effect

\footnotetext{
${ }^{40} \mathrm{~F} 1-2$, Village 5.
} 
of information. Three distinct features of the outlier villages emerge: modernization, weak traditional norms, and absence of Islam.

In one outlier village where women reported participation in civic events more than twice as often as men, follow-up interviews reveal markedly different responses. One female participant said, "We, the women of [ ], are encouraged and supported by our husbands in all the activities we undertake." A male participant went as far as to say that "women play a very important role in local development, and in our village, all the good ideas come from them." The distinguishing feature of this village is that it was more recently settled by migrants from the regional capital who were looking for more fertile land to cultivate. The village is thus more economically developed: homes are constructed with more expensive materials and there is greater public infrastructure.

In this village, people also appear less rooted in traditional Bambara culture which has strong gender norms relating to female participation in the public sphere. As evidence, there were few indications of traditional animist practices. This is in stark contrast to other rural villages visited where animist fetishes were displayed in homes and a sacred cavern administered by the village chief prohibits women's entry.

In an outlier village in the Koulikoro region where women reported higher rates of civic participation than men, the majority of the village is of the Catholic faith (Islam is the majority religion in 98 percent of villages in the sample). Focus group participants and interviews reported that village-level decisions are made democratically. Women and other marginalized groups such as youth are represented at each meeting - even those held in the chief's quarters which are strictly reserved for elderly males elsewhere. Meeting attendees are expected to be accountable to the groups they represent. When the local mayor's office holds meetings and invites only elderly male representatives from the village, the village leaders go so far as to demand that women and youth be represented as well. Among the six sample villages where Islam is not the majority religion, women do better than average 
in five 41

Interview data also suggests that the domain in which women participate matters. Interviewees suggest that women face greater barriers to participation in village-level decisionmaking than in decisions at a higher level.42 The norms of traditional Bambara culture are most salient at the village level where the village chief and elders dictate public life whereas democratically elected leaders are the principal decisionmakers at the commune level. The leader of the women's association in one village said she participates actively in communelevel meetings and activities, but is not authorized to participate in village-level meetings. In the same village, a man said it was his wife who counseled him on involvement in their chosen political party and they together discussed how to vote.

Importantly, these distinctions between formal and informal spheres of decision-making suggests that while resources may have a null or negative effect on female participation in the latter, they may still have a positive effect in the former. Indeed, a demonstration effect like that elicited by electoral quotas for women in India is also apparent in Mali. Interviewees noted that women are equal to men in politics as evidenced by the existence of female mayors and councilmembers. A male villager even said women are important in politics because they have a higher turnout rate in elections than men. This is not to say that discriminatory gender norms do not constrain women in formal positions of power. Indeed, several studies find that when the share of female representation in government increases, they too experience backlash from men (e.g., Heath, Schwindt-Bayer, and Taylor-Robinson (2005), Clayton (2015)).

While women in less modernized or developed countries may be most likely to suffer from the resource paradox due to stronger discriminatory gender norms and weaker formal protec-

\footnotetext{
${ }^{41}$ There are other documented relationships between Islam and gender disparity in socio-political outcomes. Fish (2011), for instance, finds greater gender gaps in literacy, income and political position in Muslim societies. And Field, Jayachandran, and Pande (2010) report that Muslim women in India failed to benefit from a training in business entrepreneurship that generated significant economic returns for Hindu women in the same program.

${ }^{42}$ Similarly, a development program in Afghanistan that improved female political participation at the community level was unable to change women's roles in household decisionmaking - an area governed by traditional norms Beath et al. (2013).
} 
tions of gender equality, women in developed countries are not immune from it. For example, even in the US where women's economic power and thus intra-household bargaining power is relatively high, men consistently overestimate their contributions to the household Milkie, Bianchi, Mattingly, and Robinson (2002) and still do less than half as much routine housework as women Coltrane (2000). Similarly, even though gender differences in resources such as education are relatively limited, women are still less politically interested, informed and efficacious than men Verba et al. (1997). The study's findings may thus have implications, if weaker ones, beyond the scope conditions discussed here.

\section{Conclusion}

Examining the impact of a randomly assigned civic education intervention on civic engagement demonstrates that increasing informational resources for both genders can have the unintended consequence of exacerbating the existing gender gap in civic participation - increasing rates among men while decreasing rates among women. Using qualitative data collected among participating communities, I show this phenomenon is consistent with the idea of a resource paradox in which increasing resources among women can lead to adverse effects due to pre-existing asymmetric gender norms. In the rural setting in which the information intervention was rolled out, women are typically unwelcome actors in the public sphere. Religion and custom prescribe a separate and unequal role for women in the community and civic and political activity fall outside the domain of women. Female participants in the civics course were thus considered to have deviated from an important social norm, decreasing the likelihood of future participation. Women either self-impose limits as a form of compensation or respond to explicit barriers erected by men in response to attempts to engage in civic activity following treatment.

The use of an experimental design coupled with qualitative data collection highlights the advantages of using a mixed-method approach. The field experiment soundly identifies the puzzling and, for some, unexpected finding that a civic education intervention reduced 
female participation. The focus groups and interviews then uncover mechanisms by which the intervention led to a perverse consequence for women.

These findings raise the question of why some interventions improve participation among women, while others do not. One explanation is that different gender norms and thus social costs apply to different spheres of activity. In particular, while norms of gender discrimination are well-established in the informal realm of village decision-making, norms about female participation in formal electoral politics may be less entrenched or discriminatory due to the recency of democratization or increased exposure to egalitarian norms in urban settings. Even in the qualitative data from rural Mali, several interviewees noted that women are equal to men in politics as evidenced by the existence of female elected officials. This demonstrates that even within the same society, there may be variation in gender norms across types of civic or political activity.

The divergent effects of the civics course render a nuanced policy prescription. On the one hand, an information intervention increased civic participation among a higher status group, men, and raised civic and political knowledge among both men and women. On the other hand, treatment perversely affected civic participation among lower status groups, in this case, women. Evidence of normatively divergent impacts of participatory interventions from this and other studies suggests future attempts should be more attuned to the social constraints faced by women and other marginalized groups. One immediate and low-cost remedy would be to deliver democracy promotion interventions to women only or to women and men separately - an idea advocated by men in treatment villages who said custom and religion are intolerant of the mixing of genders in public. This has been practiced elsewhere to increase the voice and confidence of female participants and even sometimes demonstrate to men the value of female input Cornwall (2003). It will not, however, mitigate the deeper issue of repressive gender norms. That a civic education course failed to instill democratic ideals such as equal opportunity casts doubt on the ability of brief external interventions to alter social norms. Such a shift will likely require a combination of grassroots mobilization 
Tripp (2001) and longer-term investment from outside actors. 


\section{References}

Agarwal, B. (1994). A field of one's own: Gender and land rights in south asia. Cambridge: Cambridge University Press.

Barnes, T. D., \& Burchard, S. M. (2013). "engendering" politics the impact of descriptive representation on women's political engagement in sub-saharan africa. Comparative Political Studies, 46(7), 767-790.

Beaman, L., Chattopadhyay, R., Duflo, E., Pande, R., \& Topalova, P. (2009). Powerful women: does exposure reduce bias? The Quarterly Journal of Economics, 124(4), 1497-1540.

Beath, A., Christia, F., \& Enikolopov, R. (2013). Empowering women through development aid: Evidence from a field experiment in afghanistan. American Political Science Review, 107(3), 540-557.

Bhavnani, R. R. (2009). Do electoral quotas work after they are withdrawn? evidence from a natural experiment in india. American Political Science Review, 103(1), 23-35.

Bleck, J. (2011). Countries at the crossroads: Mali.

Bleck, J. (2013). Do francophone and islamic schooling communities participate differently? disaggregating parents' political behaviour in mali. The Journal of Modern African Studies, 51(03), 377-408.

Bratton, M., Alderfer, P., Bowser, G., \& Temba, J. (1999). The effects of civic education on political culture: Evidence from zambia. World Development, 27(5), 807-824.

Burns, N., Schlozman, K. L., \& Verba, S. (2001). The private roots of public action: Gender, equality, and political participation.

Chattopadhyay, R., \& Duflo, E. (2004). Women as policy makers: Evidence from a randomized policy experiment in india. Econometrica, 72(5), 1409-1443.

Clayton, A. (2015). Women's political engagement under quota-mandated female representation evidence from a randomized policy experiment. Comparative Political Studies, 48(3), 333-369. 
Coltrane, S. (2000). Research on household labor: Modeling and measuring the social embeddedness of routine family work. Journal of Marriage and family, 62(4), 12081233.

Cornwall, A. (2003). Whose voices? whose choices? reflections on gender and participatory development. World development, $31(8)$, 1325-1342.

Dahl, R. A. (1972). Polyarchy: participation and opposition (Vol. 54). Yale University Press.

Desposato, S., \& Norrander, B. (2009). The gender gap in latin america: Contextual and individual influences on gender and political participation. British journal of political science, $39(01), 141-162$.

Duflo, E. (2012). Women empowerment and economic development. Journal of Economic Literature, 50(4), 1051-1079.

Field, E., Jayachandran, S., \& Pande, R. (2010). Do traditional institutions constrain female entrepreneurship? a field experiment on business training in india. The American Economic Review, $100(2), 125-129$.

Finkel, S. E. (2002). Civic education and the mobilization of political participation in developing democracies. The Journal of Politics, 64(04), 994-1020.

Finkel, S. E., Sabatini, C. A., \& Bevis, G. G. (2000). Civic education, civil society, and political mistrust in a developing democracy: The case of the dominican republic. World Development, 28(11), 1851-1874.

Fiorina, M. P. (1999). Extreme voices: A dark side of civic engagement. In T. Skocpol \& M. P. Fiorina (Eds.), Civic engagement in american democracy (Vol. 395, pp. 405-13). Washington, DC: Brookings Institution Press.

Fish, M. S. (2011). Are muslims distinctive?: A look at the evidence. New York: Oxford University Press USA.

Galston, W. A. (2001). Political knowledge, political engagement, and civic education. Annual review of political science, 4 (1), 217-234. 
Gine, X., \& Mansuri, G. (2011). Together we will: Evidence from a field experiment on female voter turnout in Pakistan. World Bank Policy Research Working Paper No. 5692.. (http://elibrary.worldbank.org/doi/abs/10.1596/1813-9450-5692)

Gottlieb, J. (2015). Does raising voter expectations improve accountability? a field experiment in mali. American Journal of Political Science.

Grossman, G., Humphreys, M., \& Sacramone-Lutz, G. (2013). Does information technology flatten interest articulation? evidence from uganda.

Heath, R. M., Schwindt-Bayer, L. A., \& Taylor-Robinson, M. M. (2005). Women on the sidelines: Women's representation on committees in latin american legislatures. American Journal of Political Science, 49(2), 420-436.

Hill, K. Q., \& Matsubayashi, T. (2005). Civic engagement and mass-elite policy agenda agreement in american communities. American Political Science Review, 99(02), 215224 .

Inglehart, R., \& Norris, P. (2003). Rising tide: Gender equality and cultural change around the world. Cambridge University Press.

Isaksson, A.-S., Kotsadam, A., \& Nerman, M. (2014). The gender gap in african political participation: testing theories of individual and contextual determinants. Journal of Development Studies, 50(2), 302-318.

Jung, D., Ferree, K. E., Gibson, C., \& Dowd, R. A. (2012). Getting out the vote, uganda style: Social and political context and turnout in an african election. In Apsa 2012 annual meeting paper.

Kittilson, M. C., \& Schwindt-Bayer, L. A. (2012). The gendered effects of electoral institutions: Political engagement and participation. Oxford University Press.

Logan, C., \& Bratton, M. (2006). The political gender gap in africa: Similar attitudes, different behaviors. Afrobarometer Working Paper No. 58 .

Mabsout, R., \& Van Staveren, I. (2010). Disentangling bargaining power from individual and household level to institutions: Evidence on women's position in ethiopia. World 
Development, 38(5), 783-796.

Milkie, M. A., Bianchi, S. M., Mattingly, M. J., \& Robinson, J. P. (2002). Gendered division of childrearing: Ideals, realities, and the relationship to parental well-being. Sex roles, 47(1-2), 21-38.

Paluck, E. L. (2010). Is it better not to talk? group polarization, extended contact, and perspective taking in eastern democratic republic of congo. Personality and Social Psychology Bulletin, 36(9), 1170-1185.

Quisumbing, A. R., et al. (2003). Household decisions, gender, and development: a synthesis of recent research. International Food Policy Research Institute.

Reynolds, A. (1999). Women in the legislatures and executives of the world: Knocking at the highest glass ceiling. World Politics, 51(04), 547-572.

Rozelle, S., \& Pang, X. (2006). A vote of confidence? voting protocol and participation in china's village elections. Freeman Spogli Institute of International Studies, Stanford University. Retrieved from http://iis-db.stanford.edu/pubs/21654/A_Vote_of _Confidence.pdf

Tripp, A. M. (2001). The politics of autonomy and cooptation in africa: the case of the ugandan women's movement. The journal of modern African studies, 39(1), 101-128.

Turrittin, J. (1988). Men, women, and market trade in rural mali, west africa. Canadian Journal of African Studies, 583-604.

USAID. (2002). Approaches to civic education: Lessons learned (Tech. Rep.). USAID Office of Democracy and Governance Technical Publication Series. Retrieved from http://transition.usaid.gov/our_work/democracy_and _governance/publications/pdfs/pnacp331.pdf

Van Staveren, I., \& Odebode, O. (2007). Gender norms as asymmetric institutions: A case study of yoruba women in nigeria. Journal of Economic Issues, 903-925.

Verba, S., Burns, N., \& Schlozman, K. L. (1997). Knowing and caring about politics: Gender and political engagement. The Journal of Politics, 59(04), 1051-1072. 
Verba, S., Schlozman, K. L., Brady, H., \& Nie, N. H. (1993). Citizen activity: who participates? what do they say? American Political Science Review, 303-318.

Verba, S., Schlozman, K. L., \& Brady, H. E. (1995). Voice and equality: Civic voluntarism in american politics. Cambridge: Harvard University Press.

Wing, S. (2012). Governing africa's changing societies: Dynamics of reform. In E. M. Lust \& S. N. Ndegwa (Eds.), (chap. Women's Rights and Family Law Reform). Lynne Rienner Publishers.

Wooten, S. (2003). Women, men, and market gardens: gender relations and income generation in rural mali. Human organization, 62(2), 166-177.

Zukin, C., Keeter, S., Andolina, M., Jenkins, K., \& DelliCarpini, M. X. (2006). A new engagement?: Political participation, civic life, and the changing american citizen: Political participation, civic life, and the changing american citizen. New York: Oxford University Press, USA. 


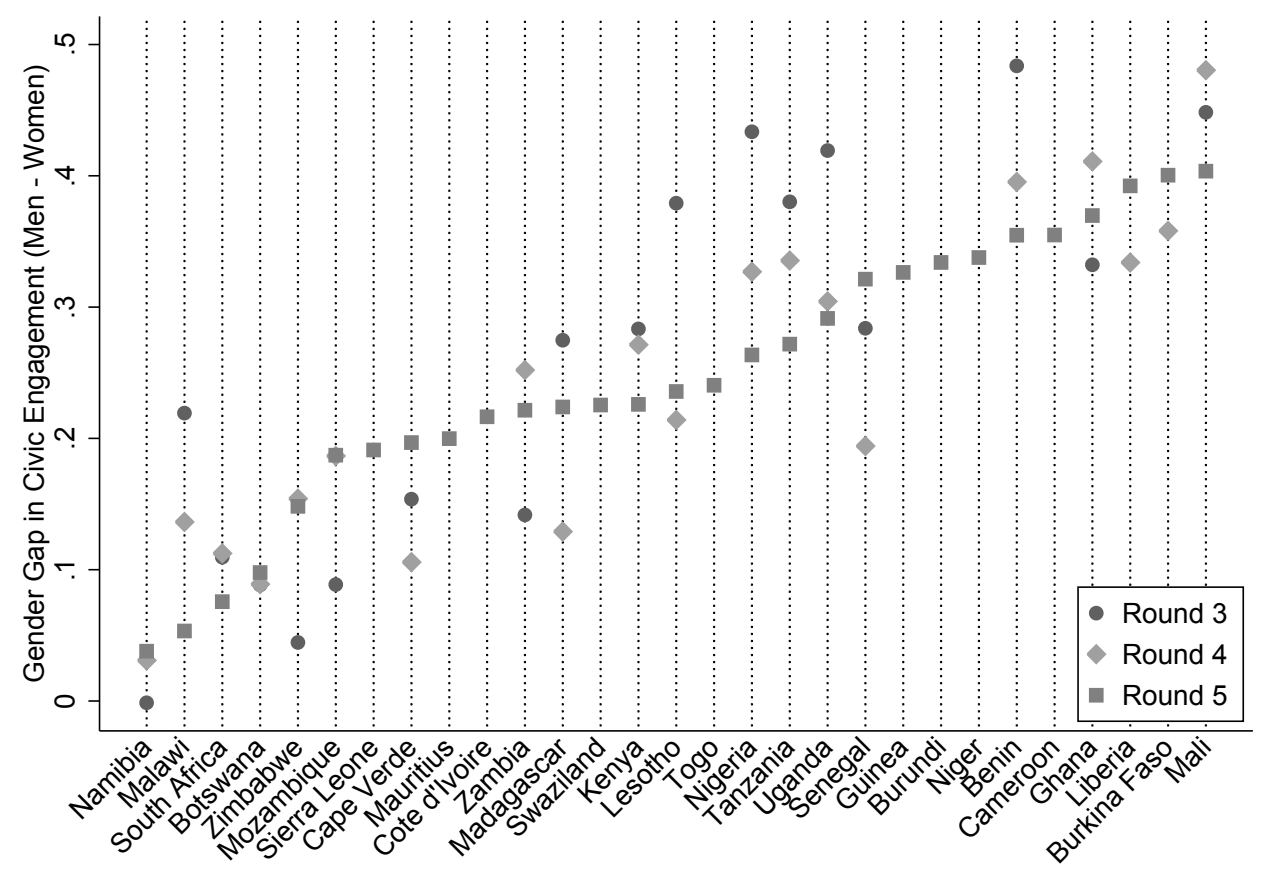

Figure 1: Comparing the Gender Gap in Civic Participation across Africa 
Table 1: Treatment effects on civic and political knowledge

\begin{tabular}{lccc}
\hline & Full sample & Men & Women \\
\hline Treatment & $0.037^{* *}$ & $0.041^{* * *}$ & $0.042^{*}$ \\
& $(0.018)$ & $(0.016)$ & $(0.023)$ \\
Treatment x Woman & 0.013 & & \\
& $(0.020)$ & & \\
Woman & $-0.253^{* * *}$ & & \\
& $(0.017)$ & & \\
\hline $\mathrm{N}$ & 5475 & 3229 & 2246 \\
\hline
\end{tabular}

Note: Standard errors in parentheses. Significance levels: ${ }^{*} \mathrm{p}<0.10,{ }^{* *} \mathrm{p}<0.05,{ }^{*} *{ }^{*} \mathrm{p}<0.01$. All models include individual-level controls, block and enumerator fixed effects and random effects at the commune and village levels. 
Table 2: Average treatment effects on civic activity by measurement instrument

\begin{tabular}{lcc}
\hline & Survey & Restricted events \\
\hline Treatment & 0.036 & 0.005 \\
& $(0.023)$ & $(0.018)$ \\
Schooling & $0.137^{* * *}$ & $0.076^{* * *}$ \\
& $(0.011)$ & $(0.011)$ \\
Leader & $0.223^{* * *}$ & $0.156^{* * *}$ \\
& $(0.021)$ & $(0.021)$ \\
Woman & $-0.154^{* * *}$ & $-0.170^{* * *}$ \\
& $(0.013)$ & $(0.014)$ \\
Chief relation & $0.053^{* * *}$ & $0.033^{* *}$ \\
& $(0.013)$ & $(0.014)$ \\
Asset ownership & $0.062^{* * *}$ & $0.037^{* * *}$ \\
& $(0.013)$ & $(0.014)$ \\
Minority ethnicity & 0.005 & $-0.048^{* *}$ \\
& $(0.018)$ & $(0.019)$ \\
Intercept & 0.038 & $0.353^{* * *}$ \\
& $(0.080)$ & $(0.069)$ \\
\hline $\mathrm{N}$ & 5472 & 5475 \\
\hline
\end{tabular}

Note: Standard errors in parentheses. ${ }^{*} \mathrm{p}<0.10,{ }^{* *} \mathrm{p}<0.05,{ }^{* * *} \mathrm{p}<0.01$. All models include block and enumerator fixed effects and random effects at the commune and village levels. 
Table 3: Heterogeneous treatment effects on civic events

\begin{tabular}{|c|c|c|c|c|c|c|}
\hline \multirow{3}{*}{ Treatment } & \multirow{2}{*}{\multicolumn{2}{|c|}{ Full sample }} & \multicolumn{4}{|c|}{ Women only } \\
\hline & & & Leader & Nonleader & Old & Young \\
\hline & $\begin{array}{c}0.044^{* *} \\
(0.021)\end{array}$ & $\begin{array}{c}0.045^{* *} \\
(0.021)\end{array}$ & $\begin{array}{l}-0.043 \\
(0.040)\end{array}$ & $\begin{array}{c}-0.062^{* *} \\
(0.028)\end{array}$ & $\begin{array}{l}-0.033 \\
(0.036)\end{array}$ & $\begin{array}{c}-0.086^{* * *} \\
(0.028)\end{array}$ \\
\hline Woman & $\begin{array}{c}-0.182^{* * *} \\
(0.022)\end{array}$ & $\begin{array}{c}-0.107^{* * *} \\
(0.022)\end{array}$ & & & & \\
\hline Treatment $\times$ Woman & $\begin{array}{c}-0.102^{* * *} \\
(0.027)\end{array}$ & $\begin{array}{c}-0.103^{* * *} \\
(0.026)\end{array}$ & & & & \\
\hline Leader & & $\begin{array}{c}0.170^{* * *} \\
(0.021)\end{array}$ & & & $\begin{array}{c}0.176^{* * *} \\
(0.039)\end{array}$ & $\begin{array}{c}0.207^{* * *} \\
(0.042)\end{array}$ \\
\hline Youth & & $\begin{array}{c}-0.068^{* * * *} \\
(0.013)\end{array}$ & $\begin{array}{l}-0.069 \\
(0.047)\end{array}$ & $\begin{array}{l}-0.026 \\
(0.024)\end{array}$ & & \\
\hline Schooling & & $\begin{array}{c}0.075^{* * *} \\
(0.011)\end{array}$ & $\begin{array}{c}0.088^{* * *} \\
(0.033)\end{array}$ & $\begin{array}{c}0.052^{* * *} \\
(0.020)\end{array}$ & $\begin{array}{c}0.114^{* * *} \\
(0.027)\end{array}$ & $\begin{array}{c}0.024 \\
(0.022)\end{array}$ \\
\hline Chief relation & & $\begin{array}{c}0.033^{* *} \\
(0.014)\end{array}$ & $\begin{array}{c}0.025 \\
(0.043)\end{array}$ & $\begin{array}{c}0.077^{* * *} \\
(0.027)\end{array}$ & $\begin{array}{c}0.037 \\
(0.035)\end{array}$ & $\begin{array}{c}0.069^{* *} \\
(0.031)\end{array}$ \\
\hline Asset & & $\begin{array}{c}0.035^{* *} \\
(0.014)\end{array}$ & $\begin{array}{c}0.049 \\
(0.042)\end{array}$ & $\begin{array}{c}0.022 \\
(0.024)\end{array}$ & $\begin{array}{l}0.065^{* *} \\
(0.031)\end{array}$ & $\begin{array}{c}0.010 \\
(0.028)\end{array}$ \\
\hline Minority & & $\begin{array}{c}-0.051^{* * *} \\
(0.019)\end{array}$ & $\begin{array}{l}-0.060 \\
(0.060)\end{array}$ & $\begin{array}{l}-0.014 \\
(0.031)\end{array}$ & $\begin{array}{l}-0.066 \\
(0.044)\end{array}$ & $\begin{array}{c}0.018 \\
(0.036)\end{array}$ \\
\hline Intercept & $\begin{array}{c}0.567^{* * *} \\
(0.065)\end{array}$ & $\begin{array}{c}0.516^{* * *} \\
(0.065)\end{array}$ & $\begin{array}{c}0.629^{* *} \\
(0.267)\end{array}$ & $\begin{array}{c}0.304^{* * *} \\
(0.098)\end{array}$ & $\begin{array}{l}0.275^{*} \\
(0.157)\end{array}$ & $\begin{array}{c}0.313^{* * *} \\
(0.094)\end{array}$ \\
\hline $\mathrm{N}$ & 5501 & 5479 & 619 & 1628 & 1003 & 1244 \\
\hline
\end{tabular}

Note: Standard errors in parentheses. ${ }^{*} \mathrm{p}<0.10,{ }^{* *} \mathrm{p}<0.05,{ }^{* * *} \mathrm{p}<0.01$. All models include block and enumerator fixed effects. 


\section{A Map of experimental sample}

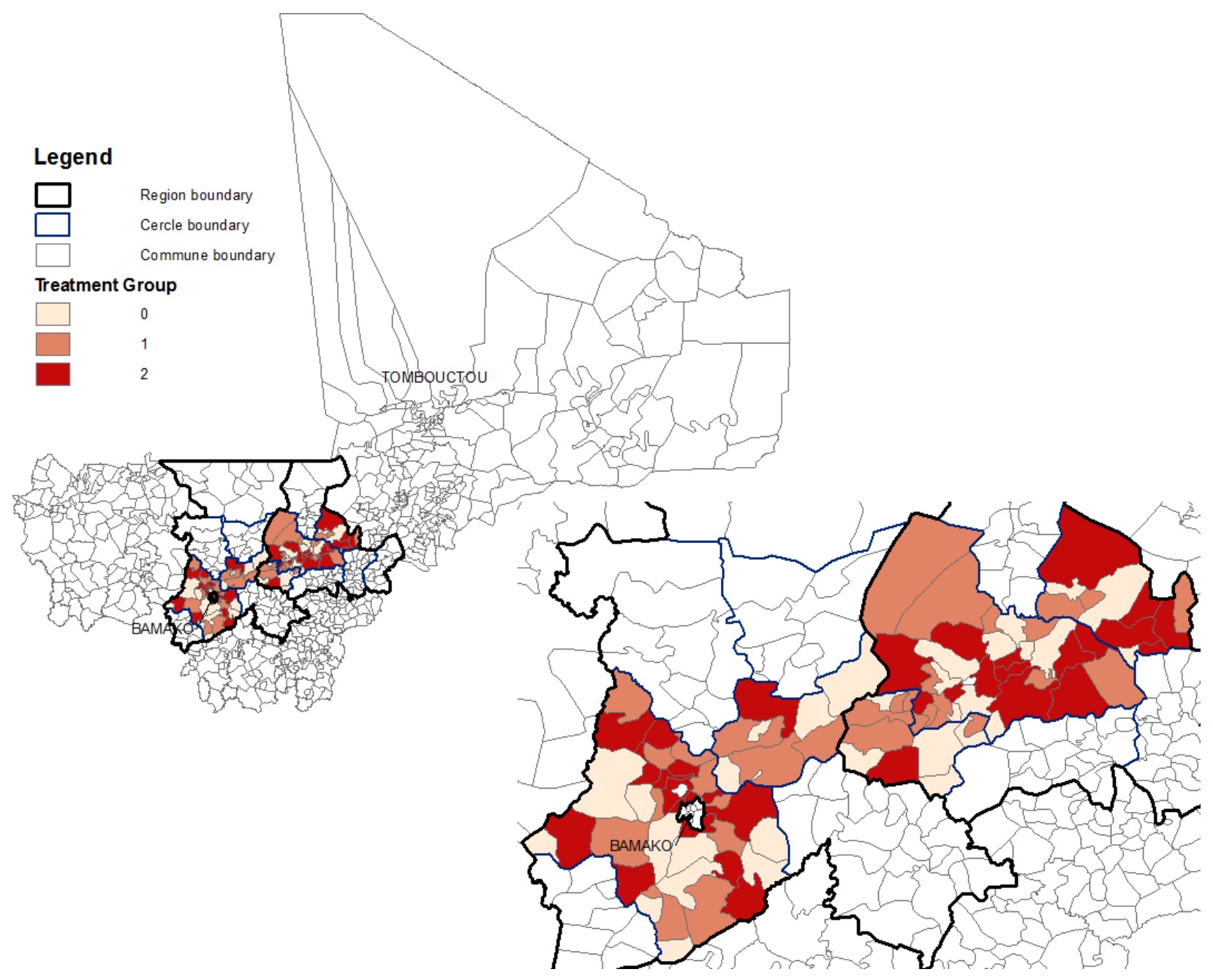

Figure A.I: Map of experimental sample 


\section{B Balance table of individual-level covariates by treat- ment status}

Table A.I: Balance on individual-level covariates by treatment status

\begin{tabular}{lcc}
\hline Covariate & Control mean & Diff: Treatment - Control \\
\hline Schooling & 0.674 & 0.025 \\
& & $(0.038)$ \\
Leader & 0.400 & -0.000 \\
& & $(0.000)$ \\
Woman & 0.406 & 0.008 \\
& & $0.005)$ \\
Chief relationship & 0.359 & 0.031 \\
& & $(0.028)$ \\
Asset ownership & 0.731 & -0.041 \\
& & $(0.030)$ \\
Minority ethnicity & 0.126 & -0.000 \\
& & $(0.018)$ \\
\hline
\end{tabular}

Note: Standard errors in parentheses. Significance levels for a two-tailed T-test: * $\mathrm{p}<0.10, * * \mathrm{p}<0.05, * * *$ $\mathrm{p}<0.01$. 


\section{Construction of the dependent variable}

Detailed descriptions in the event register allow for disaggregation of the data based on varying definitions of civic activity. The civics course curriculum discussed activities that fall under local government purview and those that do not. The former include provision of public goods and public administration. The latter comprise religious activities and those for profit or personal gain. To improve precision of estimating treatment effects, I limit the analysis to areas of civic activity I would expect treatment to impact. Blind to treatment group, civic events were coded into one of twelve categories: grievances, public goods, town hall meetings, taxes, political party, associations, personal conflicts, NGO activity, administrative, religious/traditional, and for-profit. Contrary to the other categories, I would not expect the treatment to have an effect on events categorized as religious 43 (496 events) or forprofit44 (1491 events) in nature. Not only did the civics course explicitly state that religious activities fall outside the civic domain, but Bleck (2013) finds that religious and political participation are inversely related in Mali.

The category NGO activity (1419 events, 343 of which refer to participation in treatment) helps address another measurement problem: the lack of a placebo condition. The control group received no intervention when ideally they would have received a course on something other than civic education. If individuals have a time budget for engaging in NGO activities, then their participation in the course itself is likely to decrease participation in other NGOsponsored events. For instance, a participant in the civics course may be just as likely to attend a meeting convened by the chief, but much less likely to attend the next NGO project meeting. This would bias against finding a treatment effect.

The primary dependent variable, Civic event indicator, thus excludes religious, for-profit and NGO activities, resulting in a total of 6000 of the original 9406 events. 2915 survey participants, or 52 percent of the sample, report participation in at least one event in the included categories. For most analyses, I use a binary indicator of whether or not an individual reports participation in at least one included activity on the civic event register. Such an indicator answers the question of whether treatment inspired new entrants into civic life as opposed to whether treatment generated a marginal increase in civic participation. Count data is subject to greater measurement error resulting from variation in enumerator effort to record multiple events as well as participant patience in recounting multiple events. The count data also contains several outliers that disproportionately affect the analyses.

\footnotetext{
${ }^{43}$ Organizing an evening Koran reading, distributing garb for a religious holiday, and mobilizing youth to repair the mosque are examples of religious activities.

${ }^{44}$ For-profit activities include meeting to discuss getting a better price on goods at market, collecting payment for shared crop production, or meeting to discuss animal husbandry.
} 


\section{Treatment effects on different categories of civic events}

Table A.II analyzes average treatment effects on different categories of civic events. Column 1 shows that as in the restricted sample of events, there is a significant heterogeneous treatment effect by gender in the unrestricted sample. Columns 2-4 investigate treatment effects on the three categories of events excluded from the dependent variable. There is a negative and significant treatment effect on the reporting of economic or profit-seeking activities as shown in Column 2. One explanation is treatment caused people to interpret the meaning of civic activity in a different way and thus report less on profit-seeking activities they did not deem civic in nature. There is a positive treatment effect on participation in activities sponsored by external NGOs until I remove mention of activities relating to the civics course or treatment. Excluding these events, Column 3 depicts the negative and significant effect of treatment on participation in NGO-sponsored activities. This is consistent with the explanation that individuals possess a time budget for participating in activities sponsored by external NGOs. The results suggest that if people participate in treatment, they are less likely to participate in activities sponsored by other external actors. Contrary to my expectation, there is no treatment effect on religious activities as shown in Column 4. I hypothesized that treatment would have a negative effect on religious activities because people in the treated group would no longer consider religious issues as falling within the definition of civic activities and thus report less of them than people in the control group.

Table A.II: Average treatment effects on civic activity

\begin{tabular}{lcccc}
\hline & Full register & Economic & NGOs & Religion \\
\hline Treatment & 0.012 & $-0.096^{* * *}$ & $-0.051^{* * *}$ & 0.004 \\
& $(0.023)$ & $(0.018)$ & $(0.017)$ & $(0.011)$ \\
Treatment x Woman & $-0.056^{* *}$ & $0.067^{* * *}$ & 0.024 & -0.017 \\
& $(0.025)$ & $(0.022)$ & $(0.020)$ & $(0.015)$ \\
Woman & $-0.095^{* * *}$ & $-0.075^{* * *}$ & 0.019 & $-0.045^{* * *}$ \\
& $(0.021)$ & $(0.019)$ & $(0.017)$ & $(0.013)$ \\
\hline $\mathrm{N}$ & 5475 & 5475 & 5475 & 5475 \\
\hline
\end{tabular}

Note: Standard errors in parentheses. Significance levels: ${ }^{*} \mathrm{p}<0.10,{ }^{* *} \mathrm{p}<0.05,{ }^{* * *} \mathrm{p}<0.01$. All models include individual-level controls, block and enumerator fixed effects and random effects at the commune and village levels.

The explanation that the course made female participation more salient has an observable implication that can be tested in the above data. The negative impacts of treatment should be more apparent in the categories of events that were discussed during the course and less apparent for other categories of events, e.g. the excluded ones. In Table 3 , the coefficients on the interaction terms between treatment and gender are large and negative. However, when the dependent variable is replaced with each of the three excluded categories of civic activity 
- religious, economic and NGO-sponsored - the coefficient on the interaction term is either positive or zero. The fact that the civic activities discussed during the civics course are the ones driving the disparate outcomes for men and women supports the explanation that the intervention made civic activity more salient, heightening norms against female participation in certain public activities. 


\section{E Treatment effects using count dependent variable}

Table A.III below replicates Table 3 using the count dependent variable (the raw number of events each respondent reported in the event register) rather than the binary dependent variable (whether or not the respondent reported at least one event). The first three columns in the table use the same multi-level mixed linear regression model as in Table 3 . While this is helpful for comparing across the two dependent variables, it is not the best model to fit event count data. A less biased and more efficient model for fitting event count data is the negative binomial regression used in columns 4 through 6 . Poisson models are more commonly used, but the over-dispersion of the data in this case indicates the negative binomial model is more appropriate. In all 6 columns, extreme outliers, those occurring in the top one percentile, are dropped from the data.

Table A.III: Average treatment effects by gender

\begin{tabular}{lcccccc}
\hline & \multicolumn{3}{c}{ Linear regression } & \multicolumn{3}{c}{ Negative binomial regression } \\
\cline { 2 - 7 } & Full sample & Men & Women & Full sample & Men & Women \\
\hline Treatment & $0.076^{*}$ & $0.084^{*}$ & $-0.106^{* *}$ & 0.070 & $0.072^{*}$ & $-0.132^{*}$ \\
& $(0.046)$ & $(0.050)$ & $(0.041)$ & $(0.050)$ & $(0.043)$ & $(0.071)$ \\
Treatment x Woman & $-0.171^{* * *}$ & & & $-0.209^{* *}$ & & \\
& $(0.063)$ & & & $(0.089)$ & & \\
Woman & $-0.326^{* * *}$ & & & $-0.387^{* * *}$ & & \\
& $(0.054)$ & & & $(0.064)$ & & \\
\hline $\mathrm{N}$ & 5388 & 3152 & 2236 & 5388 & 3152 & 2236 \\
\hline
\end{tabular}

Note: Standard errors in parentheses. Significance levels: ${ }^{*} \mathrm{p}<0.10,{ }^{* *} \mathrm{p}<0.05,{ }^{*} *$ p $<0.01$. All models include individual-level controls and block and enumerator fixed effects. The linear regression includes random effects at the commune and village levels. The negative binomial regression clusters standard errors at the commune level. 


\section{F Course curriculum}

The author developed the course in collaboration with the Malian Ministry of the Interior (MATCL), the National Civic Education Program (PNEC) and several international and local NGOs. The full curriculum is available on the author's website. What follows is an outline of that curriculum.

1. What is democratic decentralization?

2. Voting exercise to elect course assistant who will collect information about the village and commune as part of the course

(a) Brief history of democracy and decentralization in Mali

(b) Levels of territorial administration and their different responsibilities

(c) Main differences between democratic and authoritarian systems

(d) How the commune government engages in local development

i. Local actors involved in development

ii. Responsibilities/capacities of the local government and its actors

3. Role of the citizen

(a) Rights and responsibilities of the citizen

i. Pay taxes

ii. Right to information

iii. Participation (public meetings, elections)

(b) Key commune activities that affect citizens

i. Planning (requirement to involve citizens in the process)

ii. Budget creation

A. Size of current budget and sample line items

B. Project to be funded with 2010 ANICT funds

C. Example of Dioro commune where public debate over the budget occurred

iii. Obligation of government to communicate policies and decisions to the population

iv. Vital records such as voter registration and birth certificate (with fee amount for each service) 
(c) Avenues of recourse (each with examples of how successfully implemented in other communes)

i. The prefecture: an apolitical administrative unit that oversees communes

ii. Lobbying the commune council

iii. Sanctioning past performance

A. Questioning leaders at public meetings, particularly the public restitution B. Not voting for incumbents who performed poorly

4. Actual government performance

(a) Governance indices, commune level

i. Number of development projects realized in your village

ii. Percent of commune development projects realized in the commune seat vs. other villages

iii. Number of meetings held by commune council

(b) Governance indices, village level

i. Number of meetings attended by your village chief

ii. Number of times village chief transmitted information from meetings back to village

iii. Rate of tax recovery in village

(c) Examples of successful governance in other communes 